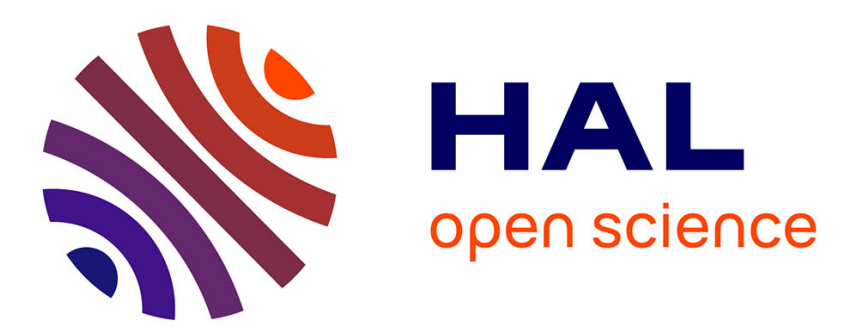

\title{
Sources of shared variability among body shape characters at marketing age in new zealand white and egyptian rabbit breeds
}

\author{
Karima Shahin, N. Hassan
}

\section{- To cite this version:}

Karima Shahin, N. Hassan. Sources of shared variability among body shape characters at marketing age in new zealand white and egyptian rabbit breeds. Annales de zootechnie, 2000, 49 (5), pp.435-445. 10.1051/animres:2000134 . hal-00889906

\section{HAL Id: hal-00889906 https://hal.science/hal-00889906}

Submitted on 1 Jan 2000

HAL is a multi-disciplinary open access archive for the deposit and dissemination of scientific research documents, whether they are published or not. The documents may come from teaching and research institutions in France or abroad, or from public or private research centers.
L'archive ouverte pluridisciplinaire HAL, est destinée au dépôt et à la diffusion de documents scientifiques de niveau recherche, publiés ou non, émanant des établissements d'enseignement et de recherche français ou étrangers, des laboratoires publics ou privés. 


\title{
Original article
}

\section{Sources of shared variability among body shape characters at marketing age in New Zealand White and Egyptian rabbit breeds}

\author{
Karima A. SHAHIN ${ }^{a *}$ N.S. HASSAN ${ }^{b}$ \\ ${ }^{a}$ Department of Animal Production, Faculty of Agriculture, Ain Shams University, \\ PO Box 68, Hadayek Shoubra, 11241 Cairo, Egypt \\ b Animal Production Research Institute, Ministry of Agriculture, Cairo, Egypt
}

(Received 30 July 1999; accepted 4 July 2000)

\begin{abstract}
Body measurements (body length, thigh circumference, shank length and chest width) of 311 rabbits representing three breeds, New Zealand White (NZW), Red Baladi (RB) and Black Baladi (BB) purebreds were subject to factor analysis. The objectives of this study were (a) to disclose the main sources of shared variability among body shape characters, (b) deduce the factors that describe these traits, (c) quantify the breed differences in size and shape and (d) predict live weight at marketing age from orthogonal body shape characters. Body conformation 'shape' appeared to be controlled by common and unique factors. The communalities ranged from 0.80 for chest width to 0.99 for thigh circumference and uniqueness (special factors) made the balance. Compared with local breeds (RB and BB), NZW had higher communality (proportion of variance for a variable that is shared in common by other variables) for chest width and lower communality for thigh circumference and body length. Our findings indicated that most of the common variability in NZW body dimensions could be accounted for by factors representing general size and chest width. Corresponding factors in RB were general size and shank length and those in BB were general size and thigh circumference. Independent body shape characters derived from factor analysis accounted for $83.4 \%, 87.9 \%$ and $90.8 \%$ of the variation in live body weight in New Zealand White, Red Baladi and Black Baladi, respectively.
\end{abstract}

New Zealand White rabbits / Egyptian rabbits / body dimensions / multicollinearity / factor analysis / shared variability

Résumé - Sources de variabilité commune parmi les caractéristiques du format corporel à l'âge de vente chez les lapins New Zealand White et deux races locales égyptiennes. Les mensurations (longueur du corps, tour de cuisse, longueur de patte et largeur de poitrine) de 311 lapins issus de trois races différentes : New Zealand White (NZW), Red Baladi (RB) et Black Baladi (BB) ont été soumises à une analyse factorielle. Les objectifs de cette étude étaient (a) d'identifier les sources principales de variabilité commune parmi les caractéristiques du format corporel, (b) de déterminer

\footnotetext{
* Correspondence and reprints
} 
les facteurs qui décrivent ces caractéristiques, (c) d'évaluer les différences en taille et en format entre les races et (d) de prévoir le poids vif à l'âge de vente à partir des caractéristiques orthogonales du format corporel. La conformation corporelle semble contrôlée par des facteurs communs et des facteurs spécifiques. Les parts de variance dues aux facteurs communs sont comprises entre 0,80 (largeur de poitrine) et 0,99 (tour de cuisse) et les facteurs uniques (facteurs spécifiques) font le complément. Comparés aux races locales (RB et BB), les NZWs ont une part de variance plus élevée (proportion de variance pour une variable qui est commune à d'autres variables) pour la largeur de poitrine et une part de variance inférieure pour le tour de cuisse et la longueur du corps. Nos résultats indiquent que la majeure partie de la variabilité commune des dimensions corporelles des NZWs peut être expliquée par des facteurs représentant d'une part la taille et d'autre part la largeur de poitrine. Les facteurs correspondants chez les RBs étaient la taille générale et la longueur de patte, et ceux chez les BBs la taille générale et le tour de cuisse. Les caractéristiques du format corporel dérivées de l'analyse factorielle comptent pour $83,4 \%, 87,9 \%$ et $90,8 \%$ dans la variation du poids vif chez les races New Zealand White, Red Baladi et Black Baladi, respectivement.

lapin New Zealand White / races locales égyptiennes / dimensions corporelles / multicollinéarité / analyse factorielle / variabilité commun

\section{INTRODUCTION}

Body measurements have been used in large animals to contrast variation in size and shape $[5,21,22]$ and to estimate body weight $[21,22]$. The correlation between body dimensions may be different if these dimensions are treated as bivariate rather than multivariate. Since body measurements are interrelated both genetically and phenotypically $[3,5,8,9,10,12,21,22]$, the analysis of these traits should consider interdependence among these traits. The presence of linear relationships among the predictors is termed multicollinearity. A number of studies have used factor analysis to eliminate redundancies from sets of interrelated variables and to extract and identify covariant variable sets that are statistically unrelated [13, 21, 22, 23, 25]. Multicollinear data analysis with multiple regression and allied techniques may limit the use of such analysis in inference and prediction [6]. Independent factor scores derived from factor analysis have been used advantageously as predictors of total carcass muscle, fat and bone and other performance traits $[16,18$, $19,20,21]$ and as a selection criterion for genetic improvement of muscle weight distribution [17].
Interrelationships among body dimensions (conformation) and body weight of animals of different breeds of rabbits treated as multivariates (simultaneously analysed) have not been investigated to any extent. One objective of this study was to investigate the hypothesis that relations involving body dimensions and body weight may be different by using orthogonal conformation traits derived from factor analysis rather than intercorrelated original traits. A second objective was to disclose the main sources of shared variability, and to deduce factors that describe body conformation of New Zealand White and Egyptian local (Red Baladi and Black Baladi) breeds of rabbits.

\section{MATERIALS AND METHODS}

\subsection{Source of data}

One-hundred and seventy-six (81 male, 95 female) New Zealand White, 93 (46, 47) Red Baladi and $42(19,23)$ Black Baladi purebred rabbits were used in this study. These animals were born over a 2 -year period and represented progeny of 9 and 40 NZW sires and dams, 8 and 13 RB sires and dams and 8 and 20 BB sires and dams. 
The animals were from the Experimental Station, Sakha, Kafr El-Sheikh, Animal Production Research Institute, Ministry of Agriculture, Egypt.

\subsection{Management of animals}

The kits were weaned at six weeks of age by removing their mothers from rearing cages. They were then sexed, tattooed and housed in groups of three individuals in commercial rabbit growing cages. The dimension of each cage was 40 (width) $\times$ 45 (depth) $\times 30$ (height $) \mathrm{cm}$. All rabbits received feed and water ad libitum from weaning to 12 weeks, the diet contained approximately $16.3 \%$ crude protein, $13.2 \%$ crude fiber, $2.5 \%$ fat and a metabolisable energy of $2600 \mathrm{kcal} \cdot \mathrm{kg}^{-1}$. All animals were maintained under similar management conditions.

\subsection{Traits considered}

The body weight in grams and dimensions in millimeters were recorded for each animal at 12 weeks of age (market age). The following live animal measurements were considered: body length, horizontal distance from the front point of the withers to the pinbone; thigh circumference, circumference at the knee-cap (patella); shank length 'tarsometatarsus', from the bottom of the foot pad to the hock; chest width 'transverse diameter of the thorax', the greatest width of chest just behind the shoulders. Lengths and width were measured with steel calipers and circumference was measured with measuring tape. To ensure accuracy, each measurement was made twice and the mean was used in subsequent analysis. The same person took all measurements and weightings throughout, thus eliminating error due to personal differences.

The data from males and females were combined since there were no significant differences between the sexes in the abovementioned traits (untabulated).

\subsection{Statistical analysis}

The data were subject to a factor analysis procedure [15]. The main source of shared variation among the interdependence of body measurements $(p)$ was expressed in terms of fewer mutually uncorrelated common factors F1, F2, Fq (where $q<p$ ) than the original measurements [7]. The first factor contained the greatest portion of the original variation and in a morphometric application of factor analysis, it was designated as a general size factor. Subsequent factors were mutually orthogonal to those preceding and to one another and contained less variation.

The model used is as follows:

$$
\mathrm{X}=\Lambda \mathrm{F}+\mathrm{U}
$$

where $\mathrm{X}=a p \times 1$ is a vector observational variables; $\Lambda=a p \times q$ a matrix of factor loading 'factor - variate correlations, the degree of correlation of the variable with factor' (the pattern matrix); $\mathrm{F}=a q \times 1 \mathrm{a}$ vector of factors (non-observable) and $\mathrm{U}=a p \times 1$ a vector of the specific 'unique' factor.

The total variance of a variable was equal to unity and can be written as the sum of common variance 'communalities' and unique variance 'uniqueness'. The communality represented the portion of the variable variance accounted for by all common factors and the uniqueness, represented the portion of the variable variance not ascribable to its correlation with other variables.

A build up stepwise multiple regression was used to predict body weight from the orthogonal factor scores derived from factor analysis. Attaining the 5\% level of significance was the predetermined criterion for entering the independent variables. Their sequence of retention followed a descending order for the amount of variance explained. The program terminated when the last independent variable entering the equation had an insignificant regression coefficient. 


\section{RESULTS AND DISCUSSION}

\subsection{Original 'non-independent' variables}

Table I presents the means, standard deviations and coefficient of variability for live weight and dimensions at 12 weeks of age for various breed groups. In NZW, the average body weight at 12 weeks was $1171 \mathrm{~g}$. The corresponding value reported by Mgheni et al. [11] was $1180 \mathrm{~g}$ and that reported by Balat et al. [2] was $1131 \mathrm{~g}$. The relatively low body weight in the present study as compared to the respective trait found in temperate regions may have been due to unfavourable environmental factors, such as temperature and food supply.

Body weight varied more ( $\mathrm{CV}$ ranged from $21.1 \%$ to $27.6 \%$ ) than any of the measurements (CV ranged from $8.5 \%$ to $15.9 \%$ ).
It is evident that body dimensions are more reliable indexes of body size than body weight. The flesh dimensions (thigh circumference and chest width) were more variable (CV ranged from $12.4 \%$ to $15.9 \%$ ) than the skeletal dimensions (body length and shank length) (CV ranged from $8.5 \%$ to $10.3 \%$ ). Variations in body weight and measurements in Red Baladi rabbits were higher than corresponding variations in either Black Baladi or New Zealand White.

\subsection{Their relationship with each other and live body weight}

Correlation coefficients among the original interdependence body shape characters for various breeds at 12 weeks are given in Table II. The magnitude of the correlation among the variables was similar for local

Table I. Means, standard deviations (SD) and coefficients of variation (CV \%) for live body weights and measurements of various rabbit breeds.

\begin{tabular}{|c|c|c|c|c|c|c|c|c|c|}
\hline & \multicolumn{3}{|c|}{ New Zealand White } & \multicolumn{3}{|c|}{ Red Baladi } & \multicolumn{3}{|c|}{ Black Baladi } \\
\hline & Mean & SD & $\mathrm{CV} \%$ & Mean & SD & $\mathrm{CV} \%$ & Mean & SD & $\mathrm{CV} \%$ \\
\hline Body weight & 1171.3 & 263.4 & 22.5 & 1065.0 & 294.3 & 27.6 & 1118.6 & 235.8 & 21.1 \\
\hline Body length & 279.8 & 24.4 & 8.7 & 273.5 & 28.2 & 10.3 & 280.1 & 27.5 & 9.8 \\
\hline Thigh circumference & 111.6 & 14.4 & 12.9 & 105.6 & 16.8 & 15.9 & 106.9 & 16.7 & 15.6 \\
\hline Shank length & 105.2 & 8.9 & 8.5 & 104.6 & 9.0 & 8.6 & 105.4 & 9.2 & 8.7 \\
\hline Chest width & 134.1 & 16.6 & 12.4 & 127.1 & 19.3 & 15.2 & 130.5 & 18.8 & 14.4 \\
\hline
\end{tabular}

Table II. Coefficients of correlation between live body weights and body measurements of various breeds of rabbits.

\begin{tabular}{|c|c|c|c|c|c|c|c|c|c|}
\hline & \multicolumn{3}{|c|}{ New Zealand White } & \multicolumn{3}{|c|}{ Red Baladi } & \multicolumn{3}{|c|}{ Black Baladi } \\
\hline & BW & $\mathrm{BL} \quad \mathrm{TC}$ & SL & BW & $\mathrm{BL} \quad \mathrm{TC}$ & SL & BW BL & $\mathrm{TC}$ & SL \\
\hline \multicolumn{10}{|l|}{ Body weight (BW) } \\
\hline Body length (BL) & 0.811 & & & 0.863 & & & 0.862 & & \\
\hline Thigh circumference (TC) & 0.840 & 0.692 & & 0.887 & 0.806 & & 0.8430 .652 & & \\
\hline Shank length (SL) & 0.754 & 0.7490 .655 & & 0.724 & 0.7710 .641 & & 0.8430 .894 & 0.647 & \\
\hline Chest width (CW) & 0.752 & 0.6210 .713 & 0.581 & 0.870 & 0.7830 .887 & 0.656 & 0.8320 .778 & 0.649 & 0.764 \\
\hline
\end{tabular}

All correlation coefficients were highly significant $(P<0.01)$. 
(RB and BB) and NZW breeds. Body measurements were highly intercorrelated. Blasco et al. [3], Niedź wiadek [12] and Lukefahr and Ozimba [10] reported similar findings. Body weight was positively correlated with various dimensions, whereas thigh circumference $(r=0.846$ for NZW and $r=0.887$ for $R B$ ) was found to have the highest correlation with live body weight. In Black Baladi, the highest correlation (0.894) was found between thigh circumference and body length. The correlation of body weight with body length and chest width in NZW was 0.811 and 0.752 , respectively; corresponding values reported by Ayyat et al. [1] were 0.620 and 0.369. Lukefahr and Ozimba [10] found a correlation of 0.57 between body weight and body length.

In local breeds, the lowest correlation $(r=0.641$ for $\mathrm{RB}$ and $\mathrm{r}=0.647$ for $\mathrm{BB})$ was found between thigh circumference and shank length, while in NZW, the lowest correlation (0.581) was found between chest width and shank length (Tab. II).

\subsection{Varimax rotated 'independent' factors. 'Their interpretation'}

Two common factors have been identified, which contributed for from $87.0 \%$ to
$91.6 \%$ of the variability of the original 4 variables, leaving 13 to $7.4 \%$ to the 4 'special' factors (Tab. III). The first factor (FI) ('general size') was characterised by high positive loadings (factor - variate correlations) on all body dimensions other than chest width in NZW, shank length in RB and thigh circumference in BB (Tab. III and Fig. 1). The coefficient associated with thigh circumference dominated the first factor in Red Baladi and is by itself a rather good estimator of general size. The correlation between this factor and thigh circumference in RB was higher than that in either NZW or $\mathrm{BB}$, while the correlation between first factor and body length in $\mathrm{BB}$ was higher than the corresponding correlation in either NZW or RB. This factor explained $25 \%, 79 \%$ and $14 \%$ of the total phenotypic variance in thigh circumference and explained $69 \%, 47 \%$ and $81 \%$ of the total phenotypic variance body length in NZW, RB and BB, respectively. The first factor 'general size' accounted for $75 \%$ of the variance in NZW, for $80 \%$ in BB and for $81 \%$ in the Red Baladi. Ricard and Rouvier [14] used a principal component analysis in examining the covariance structure of nine linear body shape characters. The population consisted of 150 Cornish cockerels of 59 days of age. They found

Table III. Explained variation associated with rotated factor analysis along with communalities for each variables. Correlation between factor score coefficients and original variables in various rabbit breeds.

\begin{tabular}{|c|c|c|c|c|c|c|c|c|c|}
\hline & New & Zealan & nd White & & $\operatorname{Red~B}$ & aladi & & lack B & Baladi \\
\hline & & mmon $\mathrm{f}$ & factors & & mmon & factors & & mmon $\mathrm{f}$ & factors \\
\hline & 1 & $2 c$ & communality & 1 & $2 c$ & communality & 1 & $2 c$ & communality \\
\hline Body length & 0.828 & 0.412 & 0.855 & 0.684 & 0.641 & 0.878 & 0.898 & 0.335 & 0.918 \\
\hline Thigh circumference & 0.502 & 0.756 & 0.824 & 0.891 & 0.346 & 0.914 & 0.369 & 0.927 & 0.995 \\
\hline Shank length & 0.890 & 0.311 & 0.889 & 0.343 & 0.925 & 0.974 & 0.896 & 0.328 & 0.910 \\
\hline Chest width & 0.294 & 0.909 & 0.913 & 0.874 & 0.364 & 0.897 & 0.795 & 0.416 & 0.807 \\
\hline$\%$ of total variance & 75.2 & 11.8 & & 81.2 & 10.4 & & 80.0 & 10.7 & \\
\hline Description & $\begin{array}{c}\text { General } \\
\text { size }\end{array}$ & $\begin{array}{l}\text { Chest } \\
\text { width }\end{array}$ & & $\begin{array}{l}\text { General } \\
\text { size }\end{array}$ & $\begin{array}{l}\text { Shank } \\
\text { length }\end{array}$ & & $\begin{array}{c}\text { General } \\
\text { size }\end{array}$ & Thigh & circumference \\
\hline
\end{tabular}




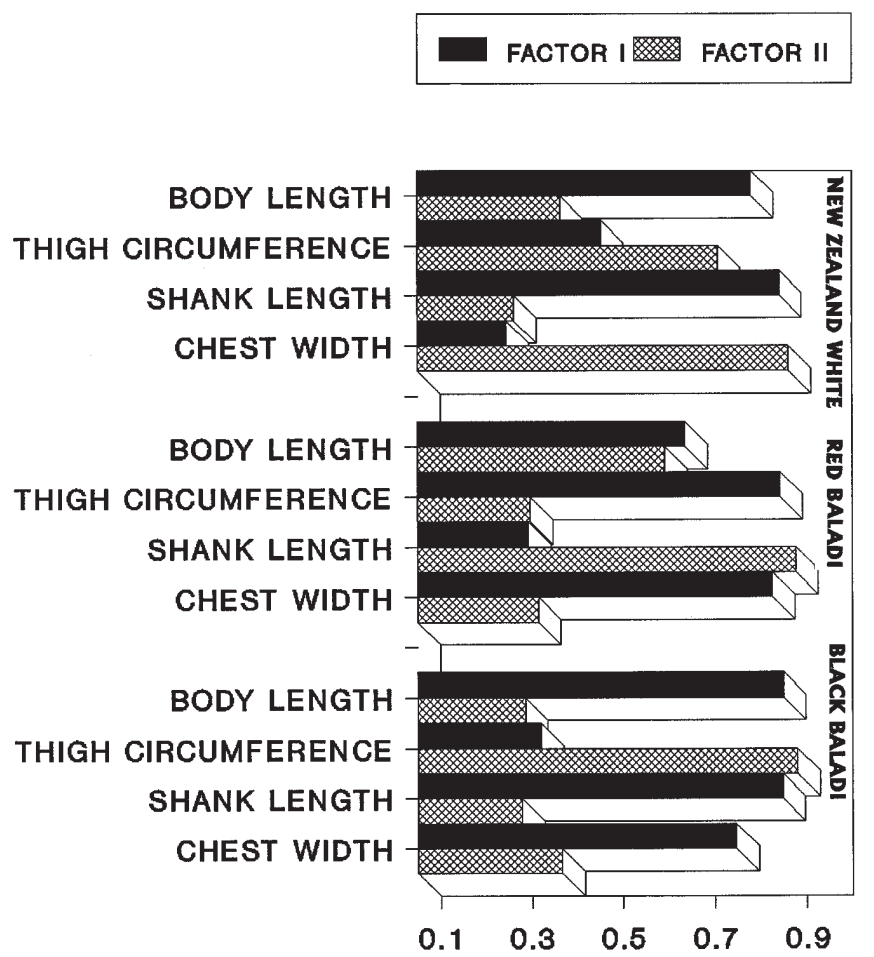

Figure 1. Correlations between factor score coefficients and original shape characters in the three breed of rabbits. that the first principal component 'general size' accounted for $59 \%$ of the variation among body shape characters. This component was best represented by trunk length, shank length and leg length. In large animals, Shahin et al. [21] used factor analysis to deduce the factors that control body shape characters. Four-hundred and sixty three young growing Egyptian buffalo bulls were involved. The first 'general size' factor was characterised by high positive loadings on all body shape characters; the variables associated with body length had the highest loading, followed by heart girth and abdominal girth. This factor accounted for $75 \%$ of the variation in the 13 original body shape characters.

The subsequent factor which was mutually orthogonal to the first, presented patterns of variation independent of general size (multicollinearity was no longer present). The second factor (FII) was not sim- ilar in the three breeds. This factor accounted for a further $11.8 \%$ of the variance in NZW, $10.4 \%$ in RB and $10.7 \%$ in Black Baladi. In NZW this factor had high loadings for chest width and thigh circumference, while in $\mathrm{RB}$, it had high loadings for shank length and body length. In BB, it had a high loading for thigh circumference. It is worth mentioning that, in NZW, the correlation of chest width and the second factor was approximately 2.9 times the magnitude of the correlation with shank length. While in Red Baladi, the correlation of shank length and the second factor was approximately 2.7 times the magnitude of the correlation with thigh circumference. In Black Baladi, the correlation of thigh circumference and the second factor was approximately 2.8 times the magnitude of the correlation with shank length. This factor could be called a chest width factor in NZW, a shank length factor in Red Baladi and a thigh circumference 
factor in Black Baladi. It is of interest to note that $83 \%$ of the variation in chest width in NZW, $86 \%$ of the variation in shank length in $\mathrm{RB}$ and $86 \%$ of the variation in thigh circumference in Black Baladi are accounted for by the second factor. It is not known whether the difference between local and NZW breeds is related to the way the weight is distributed over the body, to body conformation, to special breed characteristics peculiar to local breeds or to other factors. Tanner and Burt [24] re-analysed the rabbit measurements of Wright [26] by factor analysis to identify general vs. local growth factors controlling size in different rabbit populations. They found a basic factor 'general size' and found that factors for head and limbs controlled these traits. They found that the contribution of limb factor to total variance varied with breed; it was $3.6 \%, 18.1 \%$ and $6.7 \%$ for F1 Black-Tan Polish $\times$ Polish, F1 Polish $\times$ Flemish Giant and F2 Polish $\times$ Flemish Giant, respectively.

In brief, most of the common variability in body shape characters in New Zealand White could be accounted for by factors representing general size and chest width. Corresponding factors in Red Baladi were general size and shank length and in Black Baladi, general size and thigh circumference.

\subsection{Shared variability}

Table III lists the communalities for various variables. The variance of a variable was partitioned into a common portion 'communality' shared with some or all of the other variables and a 'uniqueness' portion, unique to that particular variable and not shared with any other variable. The results indicated that $81 \%$ to $99 \%$ of the variation in conformation traits were brought about by common factors, whereas 1 to $19 \%$ of their variation were contributed by unique factors specific for each trait. The communalities for conformation traits in NZW ranged from 0.82 for thigh circumference to 0.91 for chest width, while in $\mathrm{BB}$, the communalities ranged from 0.81 for chest width to 0.99 for thigh circumference. For $\mathrm{RB}$, the lowest (0.88) and highest (0.97) communalities were found for body length and shank length, respectively.

In NZW, thigh circumference (flesh dimension) had the lowest communality with greatest uniqueness. About $82 \%$ of the variation in thigh circumference was brought about by common factors, whereas $18 \%$ of its variation was contributed by a unique factor, specific for this trait. It is worth noting that in Black Baladi, thigh circumference had the highest communality with smallest uniqueness. In Red Baladi, shank length (skeletal dimension) had the highest communality with the smallest uniqueness of its own. About $97 \%$ of the variation in shank length was brought about by common factors, whereas $3 \%$ of the variation was contributed by a unique factor specific for shank length.

It is interesting to note that, the communality for body length and thigh circumference in Black Baladi was higher than that in Red Baladi, which in turn was higher than that in New Zealand White (Fig. 2). The ranking of breeds for chest width communality was as follows: NZW ranked first followed by RB and then BB (Fig. 2). Tanner and Burt [24] found that the communalities in mature Ayrshire cows ranged from 0.37 for width of chest to 0.89 for chest circumference. Shahin et al. [21] working with Egyptian buffalo bulls found that the communalities for skeletal dimensions (heights at withers and hips) were much higher than for flesh dimensions (rump width).

\subsection{The use of non-independent body measurements and their independent factor score to predict live body weight}

In large animals (cattle, buffalo) heart girth is frequently used as a measure of body size. In poultry, shank length is commonly 


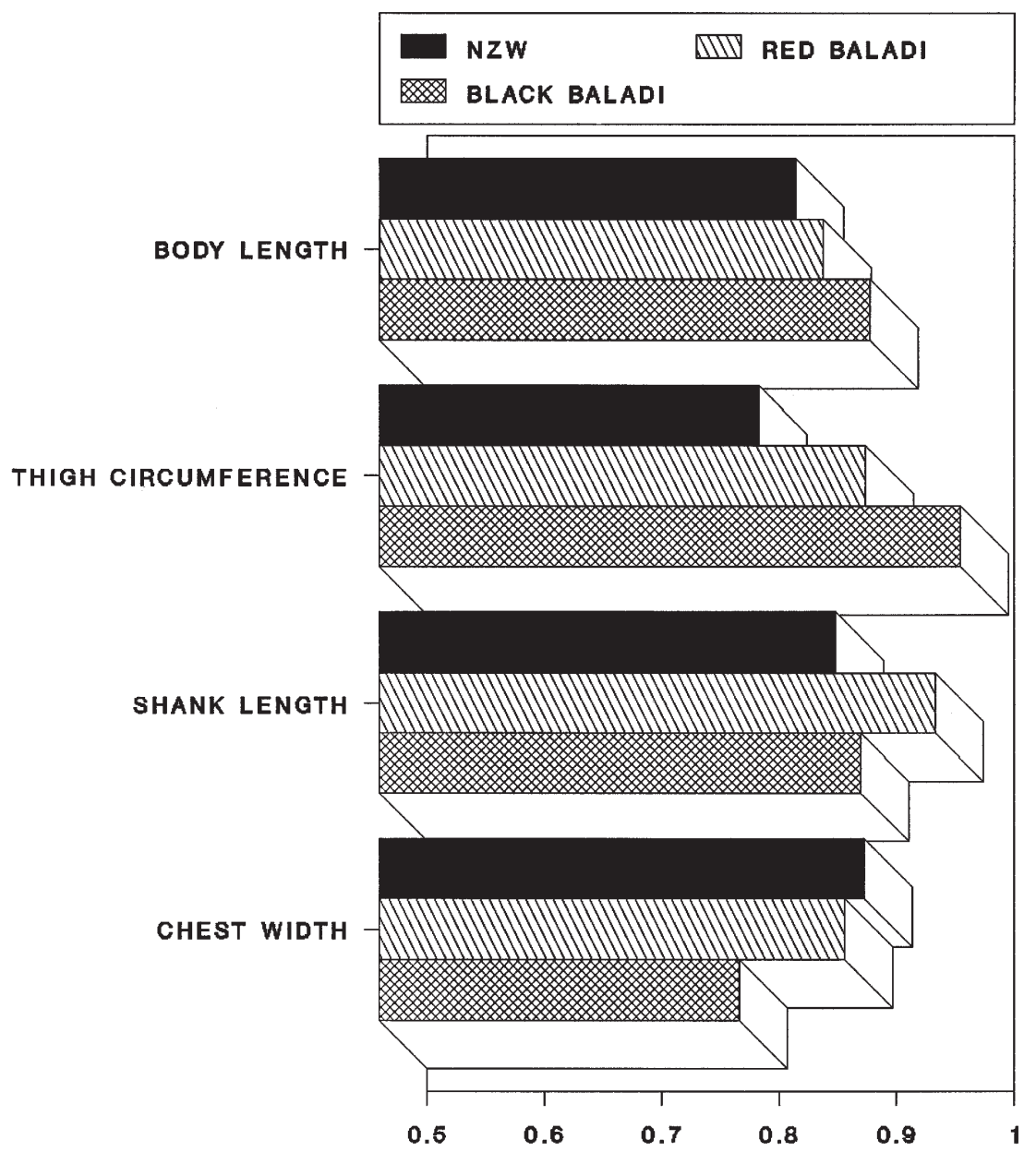

Figure 2. Values of communalities for original shape characters in New Zealand White, Red Baladi and Black Baladi.

used as a measure of body size and in the pigeon, keel length is a good means of measuring body size. In the present study with rabbits, other body dimensions such as thigh circumference and body length can be useful as measures (estimators) of body size. The usefulness of live body measurements as predictors of carcass composition and carcass merit have been investigated by Bochno et al. [4], Lukefahr and Ozimba [10] and El-Mahdy [8].
The interdependent conformation characters in one analysis and their independent rotated factors in a second analysis were used as independent variables in a multiple regression equation to predict live body weight. The parameter estimates, standard errors, $\mathrm{R}^{2}$ and residual standard deviation are given in Table IV.

The results for regression analysis for predicting live body weight from the 
4 interdependent body measurements showed that in NZW, thigh circumference alone accounted for $71.5 \%$ of the variability in live body weight and the residual standard deviation of the estimate was $141 \mathrm{~g}$ (Tab. IV). The proportion of explained variance increased from $81.3 \%$ to $83.2 \%$ when body length and chest width were added and the residual standard deviation of the estimate was then $109 \mathrm{~g}$.
Similarly, for Red Baladi, the results showed that thigh circumference alone accounted for $78.7 \%$ of the variation in live weight and the residual standard deviation was $136 \mathrm{~g}$. The proportion of variance explained increased from $85 \%$ to $88 \%$ and the residual standard deviation of the estimate decreased from 115 to $105 \mathrm{~g}$ when body length, chest width and shank length were added (Tab. IV).

Table IV. Stepwise multiple regression of live body weight (g) on original body measurements and on their orthogonal traits in various rabbit breeds.

\begin{tabular}{|c|c|c|c|c|c|c|}
\hline Step & $\begin{array}{l}\text { Independent } \\
\text { variables } \\
\text { (predictors) }\end{array}$ & Intercept & $\begin{array}{c}\text { Regression } \\
\text { coefficient }\end{array}$ & SE & $\mathbf{R}^{2}$ & $\begin{array}{l}\text { Residual } \\
\text { standard } \\
\text { deviation }\end{array}$ \\
\hline \multicolumn{7}{|c|}{ New Zealand White } \\
\hline \multicolumn{7}{|c|}{ (i) Original body measurements as independent variables } \\
\hline 1 & Thigh circumference & -555.70 & 15.48 & 0.74 & 0.715 & 140.95 \\
\hline 2 & $\begin{array}{l}\text { Thigh circumference } \\
\text { Body length }\end{array}$ & -1250.05 & $\begin{array}{l}9.98 \\
4.67\end{array}$ & $\begin{array}{l}0.83 \\
0.49\end{array}$ & 0.813 & 114.47 \\
\hline 3 & $\begin{array}{l}\text { Thigh circumference } \\
\text { Body length } \\
\text { Chest width }\end{array}$ & -1307.52 & $\begin{array}{l}7.95 \\
4.14 \\
3.24\end{array}$ & $\begin{array}{l}0.91 \\
0.48 \\
0.73\end{array}$ & 0.832 & 108.76 \\
\hline 4 & $\begin{array}{l}\text { Thigh circumference } \\
\text { Body length } \\
\text { Chest width } \\
\text { Shank length }\end{array}$ & -1437.83 & $\begin{array}{l}7.34 \\
3.21 \\
3.01 \\
4.63\end{array}$ & $\begin{array}{l}0.91 \\
0.55 \\
0.71 \\
1.42\end{array}$ & 0.832 & 105.82 \\
\hline \multicolumn{7}{|c|}{ (ii) Their orthogonal traits as independent variables } \\
\hline 1 & $\mathrm{FC} 2$ & 1171.31 & 170.52 & 15.22 & 0.419 & 201.31 \\
\hline 2 & $\begin{array}{l}\mathrm{FC} 2 \\
\mathrm{FC} 1\end{array}$ & 1171.31 & $\begin{array}{l}170.52 \\
169.59\end{array}$ & $\begin{array}{l}8.17 \\
8.17\end{array}$ & 0.834 & 108.03 \\
\hline \multicolumn{7}{|c|}{ Red Baladi } \\
\hline \multicolumn{7}{|c|}{ (i) Original body measurements as independent variables } \\
\hline 1 & Thigh circumference & -580.36 & 15.57 & 0.85 & 0.787 & 136.49 \\
\hline 2 & $\begin{array}{l}\text { Thigh circumference } \\
\text { Body length }\end{array}$ & -1156.58 & $\begin{array}{l}9.59 \\
4.42\end{array}$ & $\begin{array}{l}1.21 \\
0.72\end{array}$ & 0.850 & 115.24 \\
\hline 3 & $\begin{array}{l}\text { Thigh circumference } \\
\text { Body length } \\
\text { Chest width }\end{array}$ & -1142.15 & $\begin{array}{l}6.47 \\
3.37 \\
4.73\end{array}$ & $\begin{array}{l}1.32 \\
0.70 \\
1.09\end{array}$ & 0.876 & 105.34 \\
\hline 4 & $\begin{array}{l}\text { Thigh circumference } \\
\text { Body length } \\
\text { Chest width } \\
\text { Shank length }\end{array}$ & -1253.04 & $\begin{array}{l}6.52 \\
2.75 \\
4.53 \\
2.89\end{array}$ & $\begin{array}{l}1.31 \\
0.81 \\
1.09 \\
1.93\end{array}$ & 0.879 & 104.61 \\
\hline
\end{tabular}


Table IV. (Continued).

\begin{tabular}{|c|c|c|c|c|c|c|}
\hline Step & $\begin{array}{l}\text { Independent } \\
\text { variables } \\
\text { (predictors) }\end{array}$ & Intercept & $\begin{array}{l}\text { Regression } \\
\text { coefficient }\end{array}$ & SE & $\mathbf{R}^{2}$ & $\begin{array}{l}\text { Residual } \\
\text { standard } \\
\text { deviation }\end{array}$ \\
\hline \multicolumn{7}{|c|}{ (ii) Their orthogonal traits as independent variables } \\
\hline 1 & FC2 & 1065.00 & 235.76 & 18.47 & 0.642 & 177.12 \\
\hline 2 & $\begin{array}{l}\text { FC2 } \\
\text { FC1 }\end{array}$ & 1065.00 & $\begin{array}{l}235.76 \\
143.25\end{array}$ & $\begin{array}{l}10.81 \\
10.81\end{array}$ & 0.879 & 103.64 \\
\hline \multicolumn{7}{|c|}{ Black Baladi } \\
\hline \multicolumn{7}{|c|}{ (i) Original body measurements as independent variables } \\
\hline 1 & Body length & -952.29 & 7.39 & 0.69 & 0.744 & 120.93 \\
\hline 2 & $\begin{array}{l}\text { Body length } \\
\text { Thigh circumference }\end{array}$ & -905.76 & $\begin{array}{l}4.66 \\
6.91\end{array}$ & $\begin{array}{l}0.63 \\
1.04\end{array}$ & 0.881 & 83.58 \\
\hline 3 & $\begin{array}{l}\text { Body length } \\
\text { Thigh circumference } \\
\text { Chest width }\end{array}$ & -869.72 & $\begin{array}{l}3.30 \\
6.02 \\
3.22\end{array}$ & $\begin{array}{l}0.72 \\
0.98 \\
1.05\end{array}$ & 0.904 & 75.82 \\
\hline \multicolumn{7}{|c|}{ (ii) Their orthogonal traits as independent variables } \\
\hline 1 & FC1 & 1118.57 & 170.02 & 25.84 & 0.520 & 165.48 \\
\hline 2 & $\begin{array}{l}\text { FC1 } \\
\text { FC2 }\end{array}$ & 1118.57 & $\begin{array}{l}170.02 \\
146.88\end{array}$ & $\begin{array}{l}11.49 \\
11.49\end{array}$ & 0.908 & 73.54 \\
\hline
\end{tabular}

Each variable added for each equation added an amount $(P<0.05)$ of explained variance.

For Black Baladi, body length seems to be the major trait in determining live weight. The results of regression analysis for predicting live weight from body dimensions showed that body length alone accounted for $74.4 \%$ of the variation in live body weight and the residual standard deviation was $121 \mathrm{~g}$. $\mathrm{R}^{2}$ was progressively improved to 0.90 and the residual standard deviation reduced to $76 \mathrm{~g}$ when thigh circumference and chest width were added (Tab. IV).

These results indicate that live body weight can be predicted with a fair degree of accuracy from thigh circumference and body length; as much as $83 \%, 85 \%$ and $88 \%$ of the variation in live body weight in NZW, $\mathrm{RB}$ and $\mathrm{BB}$, respectively was accounted for by these traits. However, the use of interdependent explanatory variables should be treated with caution, since multicollinearity was shown to be associated with unsta- ble estimates of regression coefficients, rendering the estimation of unique effects of these predictors impossible.

The results of a stepwise multiple regression of live body weight on independent body shape characters (Tab. IV) showed that the first and second independent conformation traits derived from factor analysis accounted for $83.4 \%, 87.9 \%$ and $90.8 \%$ of the variation in live body weight in NZW, $\mathrm{RB}$ and $\mathrm{BB}$, respectively. The final regression equation for estimating live weight from independent factor scores for each of the three breeds is:

NZW: Live body weight $(\mathrm{g})=$

$$
1171.31+169.59 \text { FCI + 170.52 FCII }
$$

RB: Live body weight $(\mathrm{g})=$ $1065.00+235.76$ FCI + 143.22 FCII

BB: Live body weight $(\mathrm{g})=$ $1118.57+170.02$ FCI + 146.88 FCII. 
In conclusion, the factor analysis technique explores the interdependence in the original 4 body shape characters by analysing them simultaneously rather than individually. The use of orthogonal body shape characters derived from factor analysis was more appropriate than the use of the original interrelated traits for predicting live body weight. Multicollinearity of two or more independent variables makes the estimation of the unique effects of such variables impossible and thus, could lead to false inference.

\section{REFERENCES}

[1] Ayyat M.S., Marai I.F.M., El-Sayiad G.H.A., A trial to grade New Zealand White rabbits for broiler production at marketing and breeding, World Rabbit Sci. 3 (1995) 75-84.

[2] Balat M.M., Shebl M.K., Ali M.A., Tag-El-Din T.H., Comparison of Flander, Californian, Bouscat, New Zealand and Rex breeds for commercial rabbit production, Egypt. Poult. Sci. 10 (1990) 141-157.

[3] Blasco A., Estany I., Baselga M., Prediction of rabbit meat and bone weight using carcass measurements and sample cuts, Ann. Zootech. 33 (1984) 161-170.

[4] Bochno R., Lewczuk A., Janiszewska M., The suitability of some live and carcass measurements for the evaluation of carcass quality of rabbits, Rocz. Nauk. Zootech. 6 (1979) 175-183.

[5] Brown J.E., Brown C.J., Butts W.T., Evaluating relationships among immature measures of size, shape and performance of beef bulls I. Principal components as measures of size and shape in young Hereford and Angus bulls, J. Anim. Sci. 36 (1973) 1010-1020 .

[6] Chatterjee S., Price B., Analysis of collinear data, in: Regression Analysis by Example, Chap. 7, John Wiley \& Sons, New York, 1977, pp. 143-174.

[7] Darton R.A., Rotation in factor analysis, Statistician 29 (1980) 167-194.

[8] El-Mahdy M.R.M., Evaluation of live body and carcass of broiler rabbits at marketing, Egypt. J. Rabbit Sci. 8 (1998) 69-81.

[9] Johansson I., Venge O., A study of the variation in weight during growth, and in some skeletal characteristics of adult rabbits, LantbruksHögsk. Ann. 19 (1952) 161-195.

[10] Lukefahr S.D., Ozimba C.E., Prediction of carcass merit from live body measurements in rabbits of four breed types, Livest. Prod. Sci. 29 (1991) 323-334.
[11] Mgheni M., Christensen K., Kyomo M.L., Selection experiment on growth and litter size in rabbits. 1. Effect of litter size and growth, Trop Prod. 7 (1982) 217-225.

[12] Niedžwiadek S., Phenotypic and genetic correlations among some production characters of New Zealand White rabbits, Rocz. Nauk. Zootech. 10 (1983) 37-45.

[13] Nugent R.A., Notter D.R., Body measurements of crossbred calves sired by Simmental bulls divergently selected for progeny first-calf calving ease in relation to birth weight, J. Anim. Sci. 69 (1991) 2422-2433.

[14] Ricard F.H., Rouvier R., Study of conformation measurements in the chicken. V. Genetic and phenotypic variability of carcass measurements in a Cornish strain, Ann. Zootech. 17 (1968) 445-458.

[15] SAS, SAS User's Guide, Statistical Analysis System Institute, Inc., Cary, NC, USA, 1988.

[16] Shahin K.A., Analysis of muscle and bone weight variation in an Egyptian strain of Pekin ducklings, Ann. Zootech. 45 (1996) 173-184.

[17] Shahin K.A., Selection indexes using live measurements or their varimax rotated factors for improving meat weight distribution - Application on carcasses of Pekin ducks, Arch. Geflugelkd. 60 (1996) 103-108.

[18] Shahin K.A., Sources of shared variability in muscle and bone weight distribution and estimation of carcass meatiness and bone utilizing orthogonal carcass traits derived from factor analysis in Japanese quail, Ann. Zootech. 46 (1997) 175-183.

[19] Shahin K.A., Sources of shared variability in muscle and fat weight distribution in Pekin ducklings, Ann. Zootech. 48 (1999) 59-66.

[20] Shahin K.A., Sources of shared variability in meat weight distribution and conformation in Pekin ducklings, Ann. Zootech. 48 (1999) 143-150.

[21] Shahin K.A., Soliman A.M., Moukhtar A.E., Sources of shared variability for the Egyptian buffalo body shape (conformation), Livest. Prod. Sci. 36 (1993) 323-334.

[22] Shahin K.A., Soliman A.M., Moukhtar A.E. Sources of shared variability for the Egyptian cattle body shape (conformation), Indian J. Anim. Sci. 65 (1995) 759-764.

[23] Shahin K.A., Ashmawy A.A., Mourad K.A., Foda T.A., Varimax rotated factors derived from body dimensions as used to predict production criteria in buffalo cows, Indian J. Anim. Sci. 68 (1998) 946-949.

[24] Tanner J.M., Burt A.W.A., Physique in the infrahuman mammalia: A factor analysis of body measurements of dairy cows, J. Genet. 52 (1954) 36-51.

[25] Taylor St. C.S., Rollins W.C., Body size and conformation in identical twin cattle, Anim. Prod. 5 (1963) 77-86.

[26] Wright S., General, group and special size factors, Genetics 17 (1932) 603-619. 